\title{
Genes and signaling pathways involved in memory enhancement in mutant mice
}

Yong-Seok Lee

\begin{abstract}
Mutant mice have been used successfully as a tool for investigating the mechanisms of memory at multiple levels, from genes to behavior. In most cases, manipulating a gene expressed in the brain impairs cognitive functions such as memory and their underlying cellular mechanisms, including synaptic plasticity. However, a remarkable number of mutations have been shown to enhance memory in mice. Understanding how to improve a system provides valuable insights into how the system works under normal conditions, because this involves understanding what the crucial components are. Therefore, more can be learned about the basic mechanisms of memory by studying mutant mice with enhanced memory. This review will summarize the genes and signaling pathways that are altered in the mutants with enhanced memory, as well as their roles in synaptic plasticity. Finally, I will discuss how knowledge of memory-enhancing mechanisms could be used to develop treatments for cognitive disorders associated with impaired plasticity.
\end{abstract}

Keywords: Memory, Synaptic plasticity, Long-term potentiation (LTP), Hippocampus, Treatment

\section{Introduction}

The brain is the most complex organ in the human body, containing over 100 billion neurons, which form countless synapses. Furthermore, numerous signal transduction pathways interact with each other to build networks in every single neuron. Considering this complexity, it might seem naïve to think that manipulating a single molecule or signaling pathway in a limited area of the brain can enhance memory. Remarkably, however, it is not rare for this to happen. In the past two decades, advances in genetic engineering have permitted the generation of numerous mutant mouse lines in the field of neuroscience; these involve the transgenic overexpression, knockout (deletion), or knock-in (replacement) of specific genes. Although most of these mutant mice have impaired brain function, including learning and memory, a remarkable number show memory enhancement, as reviewed in this article (Figure 1, Table 1).

Assessing higher cognitive functions such as memory in rodents became possible due to the development of diverse animal behavioral tasks. For example, several tasks examine hippocampus-dependent memory in rodents. The

Correspondence: yongseok@cau.ac.kr

Department of Life Science, College of Natural Science, Chung-Ang University, Seoul 156-756, Republic of Korea
Morris water maze and contextual fear conditioning are the most commonly used hippocampal-dependent tasks. In the Morris water maze, mice are trained to find and remember the location of a platform that is hidden under the water, using spatial cues in the test room. Contextual fear conditioning is a form of associative learning test in which the animals associate the given context (training chamber) with noxious stimuli (foot shocks).

Mutant mice have also been used extensively to study the role of genes and signaling pathways involved in synaptic plasticity. Following the first report of long-term potentiation (LTP) in the dentate gyrus of the hippocampus by Bliss, Lømo and Gardner-Medwin in 1973 [57,58], the idea that long-term synaptic plasticity is a cellular mechanism essential to learning and memory has been supported and also challenged by a large body of literature [59-63]. However, recent studies strongly suggest that such long-lasting changes are indeed induced by learning in the hippocampus and amygdala [64-66].

In this article, the genes and signaling pathways that have been successfully manipulated to enhance memory in mutant mice will be reviewed. In parallel, the correlation between enhanced memory and increased LTP will also be discussed to argue that this form of synaptic plasticity plays a critical role in learning and memory. 


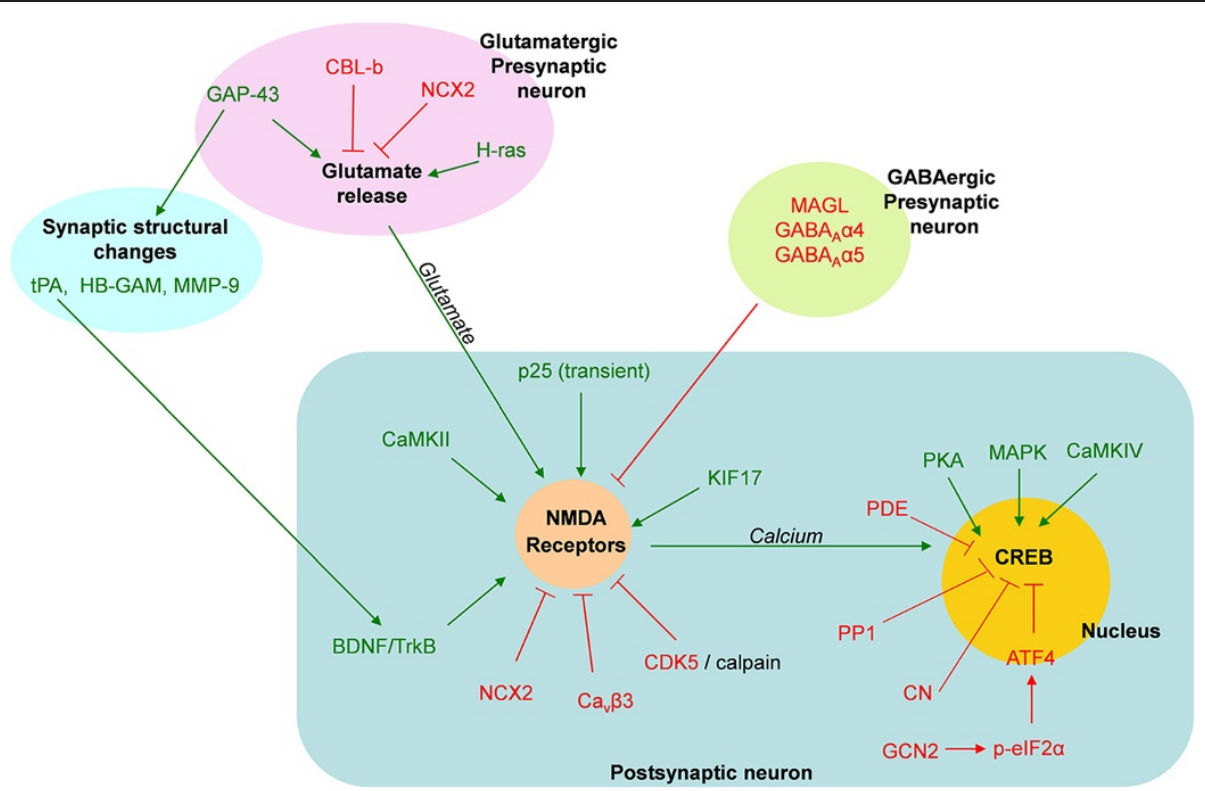

Figure 1 Molecules involved in memory enhancement. Signaling pathways in the presynaptic axonal terminal and the postsynaptic dendritic spine and nucleus are illustrated in a simplified manner. Green and red arrows indicate positive and negative regulations, respectively. Memory is enhanced either by the over expression/activation of molecules colored in green or the deletion/inhibition of molecules in red. The detailed roles of some of these molecules in LTP and memory are described in the text. Cbl-b, casitas B-lineage lymphoma-b; $\mathrm{NCX}_{2}, \mathrm{Na}^{+} / \mathrm{Ca}^{2+}$ exchanger type 2; GAP-43, growth-associated protein 43; tPA, tissue-type plasminogen activator; HB-GAM, heparin-binding growth-associated molecule; MMP-9, Matrix metallopeptidase 9; GABA, y-aminobutyric acid; MAGL, Monoacylglycerol lipase; CaMKIl, calcium calmodulin kinase II; BDNF, Brain-derived neurotrophic factor; Cdk5, Cyclin-dependent kinase 5; Cav $\beta 3$, beta intracellular subunit of the voltage-gated calcium channel; PKA, protein kinase A; PDE, phosphodiesterase; PP1, protein phosphatase 1; MAPK, mitogen-activated protein kinase; CaMKIV, calcium calmodulin kinase IV; CN, calcineurin; ATF4, activating transcription factor 4; GCN2, general control nonderepressible 2; p-elF2a, phosphorylated eukaryotic translation initiation factor 2 subunit a.

\section{Manipulating excitatory synaptic transmission Overexpression of NR2B (GluN2B)}

The $N$-methyl-D-aspartate (NMDA) receptors (NMDARs) are considered to be coincidence detectors that can associate two separate events in the brain, since they require two coincident events for activation: binding of glutamate and removal of $\mathrm{Mg}^{2+}$ by membrane depolarization $[59,63,67]$. The subsequent $\mathrm{Ca}^{2+}$ influx activates a variety of signaling molecules including $\alpha-\mathrm{Ca}^{2+} /$ calmodulindependent kinase II $(\alpha$ CaMKII) $[59,62,68,69]$. NMDAR comprises an obligatory subunit, NR1 (GluN1), and other subunits such as NR2 (GluN2A, 2B, 2C, and 2D) and NR3 (GluN3A and 3B) $[67,70,71]$. In the 1980s, Morris and his colleagues demonstrated the critical role of NMDAR in learning and LTP by showing that intraventricular infusion of the NMDAR blocker AP5 impaired spatial learning and LTP [72]. Later, this classical pharmacological experiment was revisited using elegant gene-knockout technology. Hippocampal CA1-specific deletion of NR1 impaired LTP and spatial memory without causing any confounding non-spatial learning ability deficit [73]. In addition, deletion of NR1 in the CA3 and dentate gyrus hippocampal subregions also impaired memory, though affecting its different aspects
[74-76]. Among NR2 (GluN2) subunits, NR2A (GluN2A) is predominantly expressed and its deletion causes deficits in hippocampal LTP and hippocampus-dependent learning tasks $[77,78]$. The expression of another subunit, NR2B (GluN2B), is decreased during development and the duration of NR2B (GluN2B)-mediated currents is longer than that of NR2A (GluN2A)-mediated currents, which can allow more $\mathrm{Ca}^{2+}$ influx through NMDARs [71].

Tsien, Zhuo, Liu, and their colleagues generated a transgenic mouse overexpressing NR2B in the forebrain to study its role in memory and synaptic plasticity [1]. Prolonged NMDAR activation led to enhancement of LTP in the hippocampus of the NR2B transgenic mouse, and these mutants outperformed their wild type littermates in several learning and memory tasks. Firstly, the transgenic mice showed better performance than wild type littermates in the hidden-platform version of the water maze $[1,79]$. Secondly, both contextual and cued fear memory were enhanced in the NR2B transgenic mice. In addition, fear extinction, which is also NMDARdependent and thought to be another form of active learning, was also facilitated in the mutants. It was later shown that this superiority in learning and memory is retained in aged transgenic mice [2]. The memory enhancing 
Table 1 Mutant mice with enhanced memory

\begin{tabular}{|c|c|c|c|}
\hline Mutant & Memory phenotypes & LTP phenotypes & References \\
\hline \multicolumn{4}{|c|}{ Excitatory synaptic transmission } \\
\hline NR2B (GluN2B) Tg & Enhanced in MWM, CFC, ORT, NMT & Enhanced CA1 LTP & {$[1-4]$} \\
\hline $\mathrm{Cdk5} \mathrm{cKO}$ & Enhanced in CFC, reversal learning in MWM & Enhanced CA1 LTP & [5] \\
\hline p25 Tg & Enhanced in MWM, CFC & Enhanced CA1 LTP & [6] \\
\hline Kif17 Tg & Enhanced in MWM, DMT & Not determined & [7] \\
\hline ORL1 KO & Enhanced in MWM, CFC, PA & Enhanced CA1 LTP & {$[8,9]$} \\
\hline $\mathrm{Hgf} \mathrm{Tg}$ & Enhanced in MWM & Not determined & [10] \\
\hline $\mathrm{Ca} a_{v} \beta \mathrm{KO}$ & Enhanced in MWM & Enhanced CA1 LTP & [11] \\
\hline Dao KO & Enhanced in MWM & Enhanced CA1 LTP & [12] \\
\hline \multicolumn{4}{|l|}{ Presynaptic function } \\
\hline H-ras Tg & Enhanced in MWM, CFC & Enhanced CA1, cortical LTP & [13] \\
\hline $\mathrm{Ncx2} \mathrm{KO}$ & Enhanced in MWM, CFC, ORT & Enhanced CA1 LTP & [14] \\
\hline Cbl-b KO & Enhanced in MWM (remote memory) & No change in CA1 LTP & [15] \\
\hline Gap43 Tg & Enhanced in MWM & Enhanced CA1 LTP & [16] \\
\hline \multicolumn{4}{|c|}{ Inhibitory synaptic transmission } \\
\hline $\mathrm{GABA}_{A} R$ a4 (Gabra4) KO & Enhanced in CFC, TFC & Not determined & [17] \\
\hline Magl KO & Enhanced in MWM, ORT & Enhanced CA1 LTP & [18] \\
\hline Pkr (Eif2ak2) KO & Enhanced in MWM, CFC, AFC & Enhanced CA1 LTP & [19] \\
\hline GABA $A_{A} R$ a5 (Gabra5) KO & Enhanced in MWM & Trend of enhanced CA1 LTP & [20] \\
\hline Grpr KO & Enhanced in CFC, AFC & Enhanced amygdala LTP & [21] \\
\hline \multicolumn{4}{|l|}{ Network activity } \\
\hline Becl KO & Enhanced in MWM, YM & No change in CA1 LTP; Impaired LTP in Tg & [22] \\
\hline $\mathrm{Kv} \beta 1.1 \mathrm{KO}$ & Enhanced in MWM (aged mice only) & Enhanced CA1 LTP (aged mice only) & [23] \\
\hline $\mathrm{Hcn} 1 \mathrm{KO}$ & Enhanced in MWM & Enhanced perforant path LTP & [24] \\
\hline \multicolumn{4}{|c|}{ Transcriptional regulation and its upstream molecules } \\
\hline CREB-Y134F Tg & Enhanced in MWM, CFC, SR, CD & Enhanced CA1 LTP & [25] \\
\hline CREB-DIEDML Tg & Enhanced in CFC, SR & Not determined & [25] \\
\hline $\mathrm{elF} 2 \mathrm{a}^{\mathrm{S51A}} \mathrm{Kl}$ & Enhanced in MWM, CFC, AFC & Enhanced CA1 LTP & [26] \\
\hline $\mathrm{Gcn} 2 \mathrm{KO}$ & Enhanced in MWM, impaired in CFC & Enhanced CA1 LTP & [27] \\
\hline ATF4, C/EBP Cl & Enhanced in MWM & Enhanced CA1 LTP & [28] \\
\hline CamkIV Tg & Enhanced in CFC & Enhanced CA1 LTP & [29] \\
\hline Acl Tg & Enhanced in ORT & Enhanced CA1 LTP & [30] \\
\hline$A p \circ a_{1} \mathrm{Tg}$ & Enhanced in CFC, ORT & Enhanced CA1 LTP & [31] \\
\hline Pde4d KO & Enhanced in MWM, RAM, ORT & Not determined, but see [32] & [33] \\
\hline Pde8b KO & Enhanced in MWM, CFC & Not determined & [34] \\
\hline Calcineurin $\mathrm{Cl}$ & Enhanced in MWM, AFC, ORT & Enhanced CA1 LTP & {$[35,36]$} \\
\hline $\mathrm{PP} 1 \mathrm{Cl}$ & Enhanced in MWM, ORT & Enhanced CA1 LTP & {$[37,38]$} \\
\hline \multicolumn{4}{|l|}{ Translational regulation } \\
\hline Paip2a KO & Enhanced in MWM, OLT, CFC & Enhanced CA1 L-LTP & [39] \\
\hline Fkbp12 KO & Enhanced in CFC & Enhanced CA1 L-LTP & {$[40]$} \\
\hline \multicolumn{4}{|l|}{ Epigenetic regulation } \\
\hline $\mathrm{Hdac2} \mathrm{KO}$ & Enhanced in CFC, AFC, NMT & Enhanced CA1 LTP & [41] \\
\hline \multicolumn{4}{|l|}{ miRNA biogenesis } \\
\hline Dicer1 KO & Enhanced in MWM, CFC, TFC & Enhanced CA1 LTP & {$[42]$} \\
\hline
\end{tabular}


Table 1 Mutant mice with enhanced memory (Continued)

\begin{tabular}{llll}
\hline Extracellular molecules & & & \\
\hline Mmp9 Tg & Enhanced in MWM, ORT & Enhanced CA1 LTP & [43] \\
\hline tPA (Plat) Tg & Enhanced in MWM & Enhanced CA1 LTP & [44] \\
\hline HB-GAM (Ptn) Tg & Enhanced in MWM & Enhanced CA1 LTP & [45,46] \\
\hline Other manipulations & & & \\
\hline Ncs-1 Tg & Enhanced in MWM, ORT & Enhanced perforant path LTP & [47] \\
\hline Rgs14 KO & Enhanced in MWM (learning), ORT & Enhanced CA2 LTP & [48] \\
\hline 5-HT $R$ Tg & Enhanced in CFC & Not determined & [49] \\
\hline Maoa KO & Enhanced in CFC, AFC & Not determined & [50] \\
\hline Hdc KO & Enhanced in MWM, CFC, AFC & Enhanced CA1 LTP & [51,52] \\
\hline Def45 KO & Enhanced in MWM, ORT & Not determined & [53,54] \\
\hline EC-SOD Tg & Enhanced in MWM, impaired CFC & Enhanced CA1 LTP & [55] \\
\hline S100b KO & Enhanced in MWM, CFC & Enhanced CA1 LTP & {$[56]$} \\
\hline
\end{tabular}

Tg, transgenic; KO, knockout; Kl, knock-in; $\mathrm{CKO}$, conditional $\mathrm{KO}$; $\mathrm{Cl}$, conditional inhibition; MWM, Morris water maze; CFC, contextual fear conditioning; AFC, auditory fear conditioning; TFC, trace fear conditioning; ORT, object recognition test; OLT, object location test; RAM, radial arm maze; SR, social recognition; DMT, delay matching to place task; NMT, non-match to place task; YM, Y-maze; L-LTP, late phase LTP.

effects of NR2B overexpression go beyond hippocampusdependent tasks. NR2B transgenic mice also showed enhanced working memory performance in the delay non-match-to-place T-maze task [3]. Accordingly, cortical LTP was also found to be enhanced in NR2B mutant mice [3]. Recently, Wang and colleagues overexpressed NR2B in the forebrains of rats and found that these rats showed enhanced memory and hippocampal LTP, which demonstrates that the up-regulation of NR2B results in memory enhancement in multiple species [4].

\section{Post-translational regulation of NR2B}

The function of proteins can be regulated by multiple post-translational processes such as covalent modifications, subcellular localization, and degradation. NR2B is transported along microtubules by a neuron-specific motor protein kinesin family protein 17 (KIF17) [80]. Interestingly, overexpression of KIF17 increased the synaptic expression of NR2B and enhanced spatial and working memory in transgenic mice [7], suggesting that enhanced transport of NR2B could be the cause of the enhanced learning ability, at least to some degree.

Calpain is activated by $\mathrm{Ca}^{2+}$ entering through NMDARs, and it rapidly cleaves NMDAR subunits, which are clustered with a scaffolding-protein complex that contains PSD-95; subsequently, it decreases functional NMDAR expression $[81,82]$. The proteolysis of NR2B by calpain is accelerated by interaction of the latter with Cdk5 [5]. Hawasli and colleagues generated a conditional knockout of Cdk5 in mice and found that the deletion of Cdk5 in the adult forebrain enhances contextual fear conditioning, fear extinction, reversal learning in the water maze, and LTP [5]. In addition, Cdk5 deletion was associated with a reduction of NR2B degradation that resulted in augmentation of NMDAR-mediated currents. Recently, disrupting the NR2B-Cdk5 interaction via a small interfering peptide has been shown to increase NR2B surface levels, facilitate synaptic transmission, and subsequently, improve memory in contextual fear conditioning [83]. Consistent with this, chronic activation of $\mathrm{p} 25$, a strong activator of $\mathrm{Cdk} 5$, resulted in deficits in learning and synaptic plasticity $[6,84]$. However, paradoxically, the transient expression of p25 in mouse forebrain enhanced synaptic plasticity and hippocampus-dependent memory, including contextual fear conditioning and learning in the Morris water maze [6]. This memory enhancement was accompanied by increases in numbers of dendritic spines and synapses [6]. While both NR2A phosphorylation and NMDA-mediated currents are shown to increase after the transient overexpression of p25 [6], neither NR2B expression nor NR2B-mediated currents have been examined in this conditional transgenic mutant.

\section{Other mutants with enhanced NMDAR function}

Other manipulations have indirectly enhanced NMDAR function and subsequently enhanced memory. Mice lacking the nociception receptor, opioid receptor-like-1 (ORL1), showed enhanced learning and memory in the Morris water maze, passive avoidance task, and contextual fear conditioning [8,9]. Moreover, LTP was significantly enhanced in this mutant. Since ORL1 was initially reported to inhibit adenylyl cyclase via $G$ proteins [85], an increased level of cAMP was postulated as the underlying mechanism for enhanced plasticity and learning in ORL1 knockout mice. However, a recent study showed that the deletion of ORL1 increases CaMKII activity and enhances NMDAR function, suggesting that enhanced NMDAR function might be 
responsible for the enhanced cognition in ORL1 knockout mice [8].

Transgenic mice overexpressing hepatocyte growth factor (HGF) also showed enhanced learning and memory performance in the Morris water maze [10]. Biochemical analysis revealed that NR2A and NR2B expression was significantly increased in the hippocampus of HGF transgenic mice. Taken together, these studies demonstrate that up-regulation of NMDAR function is one of the common molecular mechanisms for genetic enhancement of learning and memory. Moreover, these studies support the idea that NMDAR-dependent LTP is strongly associated with memory performance in a diverse set of behavioral tasks.

\section{Enhancing excitatory presynaptic function}

Studies of mice expressing a constitutively active form of $\mathrm{H}$-ras $\left(\mathrm{H}-\right.$ ras $\left.^{\mathrm{G} 12 \mathrm{~V}}\right)$ in axons of pyramidal neurons in the post-natal hippocampus revealed a role for Ras signaling in presynaptic neurotransmitter release in LTP and memory [13]. Presynaptic expression of H-ras ${ }^{\mathrm{G} 12 \mathrm{~V}}$ resulted in increased activation of mitogen-activated protein kinase (MAPK) and phosphorylation of its presynaptic substrate, synapsin I. In addition, these mutants showed a number of other convergent presynaptic phenotypes, including a higher number of docked vesicles, an increased frequency of mEPSCs, and altered paired-pulse facilitation. Moreover, both hippocampal LTP and hippocampal memory were enhanced in the transgenic mice [13]. Importantly, a synapsin I mutation, which alone had no measurable effect on LTP or learning, reversed the physiological and behavioral enhancements of the H-ras ${ }^{G 12 V}$ mice, indicating that H-Ras/MAPKdependent phosphorylation of synapsin I played a key role in the learning enhancements of these mutants. These results provide strong evidence that the learning enhancements described were caused by increased phosphorylation of synapsin I, and the subsequent enhancement of excitatory presynaptic function. Recently, Kaneko and colleagues showed that the rate of change in ocular dominance in response to monocular deprivation is accelerated in the mutants, as well as the rate of the recovery from the deprivation [86]. In addition, presynaptic LTP is enhanced in the primary visual cortex of developing $\mathrm{H}-\operatorname{ras}^{\mathrm{G} 12 \mathrm{~V}}$ mice (P26-30) [86].

\section{Manipulating inhibition}

Disruption of the excitation/inhibition balance has been proposed as a mechanism underlying many psychiatric disorders such as Schizophrenia, autism, and learning disabilities [87-89]. However, evidence is accumulating that memory can be enhanced by modulating inhibition. For example, pharmacological suppression of inhibition has been shown to enhance memory consolidation [90,91]. Moreover, a picrotoxin treatment that reduces inhibitory synaptic transmission lowered the threshold for LTP induction [92]. The effect of genetic reduction of tonic inhibition was examined in $\mathrm{GABA}_{\mathrm{A}} \mathrm{R} \alpha 4$ subunit knockout mice [17]. $\mathrm{GABA}_{\mathrm{A}} \mathrm{R} \alpha 4$ knockouts showed enhanced trace and contextual fear conditioning, suggesting that reducing tonic inhibition can enhance hippocampus-dependent forms of memory [17]. LTP and other forms of synaptic plasticity have yet to be tested in this mutant.

Beyond direct manipulation of the GABA receptor, some manipulations enhance memory by indirectly affecting inhibition. Monoacylglycerol lipase (MAGL) is one of the enzymes that regulate endocannabinoid $(\mathrm{eCB})$ signaling by hydrolyzing the eCB 2-arachidonoylglycerol (2-AG). Deletion of MAGL increases the level of 2-AG in the brains of MAGL knockout mice [18]. Exogenous cannabinoids impair learning and memory. In contrast, increasing the levels of 2-AG in the MAGL knockout mice enhanced learning and memory in the Morris water maze and object recognition tasks [18]. This cognitive enhancement is also accompanied by enhanced LTP in the hippocampus [18]. The cannabinoid receptor CB1 is predominantly expressed in inhibitory neurons and therefore, eCBs are implicated in the regulation of inhibitory synaptic transmission. Electrophysiological recordings suggest that the LTP enhancement in MAGLnull mutants is mediated by 2-AG-induced suppression of inhibition [18].

GABA release can be inhibited by interferon- $\gamma$, whose translation is negatively regulated by a double-stranded RNA-activated protein kinase (PKR) and eIF2 $\alpha$. In PKR knockout mice, the increased translation of interferon- $\gamma$ has been shown to increase neuronal activity in the hippocampus by reducing GABA release [19,93]. Accordingly, GABAergic inhibition was decreased in PKR knockout mice [19]. PKR knockouts showed memory enhancement in the Morris water maze, and contextual and auditory fear conditioning. Memory extinction in contextual fear conditioning was also enhanced in PKR mutants [19]. Network excitability was increased in hippocampal slices from PKR knockout mice due to reduced GABAergic inhibition [19].

One of the key molecules for regulating neuronal excitability is the potassium channel. BEC1 (KCNH3) is a member of the ether-a-go-go (KCNH) family of voltagegated $\mathrm{K}^{+}$channels that is preferentially expressed in the forebrain. Deletion of BEC1 increased the excitability of hippocampal pyramidal neurons and enhanced working memory, spatial memory, and attention [22]. In contrast, overexpression of BEC1 in the forebrain impaired memory and LTP [22]. Taken together, these results suggest that manipulating the balance of excitation/inhibition by either reducing inhibition or increasing network excitability within an appropriate range might be a promising strategy for cognitive enhancement. 


\section{Manipulating transcriptional regulation Enhancing CREB function}

The formation of long-term memories requires synthesis of new mRNA and proteins. Synaptic stimulation or learning activates multiple signaling pathways to orchestrate gene transcription and translation. Accordingly, overexpression of transcriptional activators such as CCAAT enhancer-binding protein (C/EBP) and LAPS18-like protein (LLP) has been shown to lower the threshold for long-term synaptic plasticity in the marine snail Aplysia [94,95].

cAMP response element-binding protein (CREB), a basic leucine zipper transcription factor, is critically involved in long-term plasticity and memory in both invertebrates and vertebrates [60,96-102]. In mammals, CREB-deficient mice have impaired LTP and long-term memory [96]. By contrast, the threshold for late phase LTP (L-LTP) was lowered in the hippocampus of mice expressing the constitutively active form of CREB (VP16-CREB) [103]. Kida and colleagues generated two transgenic mouse lines expressing dominant active CREB mutations in the forebrain: CREB-Y134F, which displays a higher affinity for PKA and CREB-DIEDML, which constitutively interacts with CBP [25]. CREB-Y134F mutant mice outperformed their wild type littermates in social recognition, contextual fear conditioning, context discrimination, and the Morris water maze task. Similarly, the CREB-DIEDML mutant also showed enhanced memory in social recognition and contextual fear conditioning, which are hippocampusdependent tasks [25]. LTP was also enhanced in CREBY134F mutant mice, demonstrating that enhancing CREB function facilitates both synaptic plasticity and memory [25].

CREB activity can be modulated by other regulatory proteins [104]. Overexpression of CREB2, which is a negative regulator of CREB in Aplysia, blocked longterm facilitation, while inhibiting CREB2 lowered the threshold for long-term facilitation induced by serotonin treatments $[105,106]$. This suggests that the balance between positive and negative regulation of CREB can determine the polarity and/or strength of synaptic plasticity and memory both in invertebrates and vertebrates. Activating transcription factor-4 (ATF4), a mammalian homolog of Aplysia CREB2, is a negative regulator of CREB in vertebrates [107]. Chen and colleagues found that the forebrain-specific expression of a broad-spectrum dominant negative inhibitor of the C/EBP family (EGFP-AZIP) suppresses ATF4 expression [28]. This manipulation shifted the transcriptional balance in favor of activation of CREBdownstream genes and lowered the threshold for LTP and memory formation [28]. Mutant mice showed enhanced learning when they were trained in the Morris water maze using a relatively weak training protocol, and a single train of tetanus, which normally induces only E-LTP, could induce transcription-dependent L-LTP in the mutants [28].
These data suggest that relief of transcriptional repression can be an evolutionarily conserved strategy for enhancing learning and memory.

Phosphorylation of the $\alpha$-subunit of eIF2 can stimulate the translation of ATF4 mRNA [108,109]. Deletion of GCN2, a conserved eIF2 $\alpha$ kinase, has been shown to reduce the phosphorylation of eIF $2 \alpha$ and suppress the translation of ATF4 mRNA [27]. The threshold for L-LTP was lowered and spatial memory was enhanced by this manipulation when the mutants were trained using a weak training protocol [27].

To directly examine the role of eIF $2 \alpha$ phosphorylation in synaptic plasticity and memory, eIF $2 \alpha$ heterozygous knock-in mice $\left(\mathrm{eIF} 2 \alpha^{+/ \mathrm{S} 51 \mathrm{~A}}\right)$ were generated, in which the phosphorylation of eIF $2 \alpha$ is blocked [26]. In this mutant, the protein level of ATF4 was significantly reduced. Similarly to GCN2 knockout mice, the threshold for L-LTP was lowered and the mutants showed improved learning and memory in a variety of behavioral tasks, including contextual and cued fear conditioning, conditioned taste aversion, and latent inhibition [26].

\section{Positive regulators of CREB}

Adenylyl cyclases (ACs) play crucial roles in synaptic plasticity and memory in the mammalian brain by coupling $\mathrm{Ca}^{2+}$ currents through NMDARs to cAMP signaling [110]. Of the ACs, AC1 and AC8 are neuron-specific [110]. Wang and colleagues overexpressed AC1 in mouse forebrain to examine whether up-regulation of AC1 can enhance memory [30]. AC1 overexpression enhanced LTP, and AC1 transgenic mice showed enhanced memory in the object recognition task. After training in the object recognition task, activation of MAPK and CREB was significantly higher in mutants compared to the control mice, supporting the hypothesis that up-regulation of CREB function is associated with memory enhancement [30].

Isiegas and colleagues developed a novel transgenic system that can conditionally activate cAMP signaling in mouse forebrain by overexpressing a $\mathrm{G}_{\mathrm{s}}$-coupled octopamine receptor cloned from Aplysia [31,111]. Administration of octopamine, which is not endogenously expressed in the mammalian nervous system, activated cAMP signaling and enhanced hippocampal LTP and memory in the object recognition task [31].

\section{Negative regulators of CREB}

Phosphodiesterases (PDEs) hydrolyze cAMP, and there are 11 families of PDEs in mammals. Among the four subtypes of PDE4s (A, B, C, and D), PDE4D knockout mice have shown memory enhancement in the radial arm maze, Morris water maze, and object recognition test [33]. Activation of CREB was also increased in the PDE4D knockout. Recently, deletion of PDE8B was shown 
to enhance memory in contextual fear conditioning, the Morris water maze, and an appetitive instrumental conditioning task [34].

\section{Manipulating translational regulation}

Translation of protein can be regulated at multiple levels, from the initiation of translation to protein degradation. PABP-interacting protein 2 (PAIP2) negatively regulates translational initiation by inhibiting poly (A)-binding protein (PABP). PAIP2A was found to be degraded in response to either neural activation or behavioral training in contextual fear conditioning, suggesting that PAIP2A might be a negative regulator of plasticity and learning [39]. To examine whether PAIP2A is indeed involved in memory formation, Khoutorsky and colleagues generated PAIP2A knockout mice [39]. PAIP2A knockouts showed memory enhancements in multiple behavioral tasks including the Morris water maze, contextual fear conditioning, and object-location memory tasks, which all depend on the hippocampus. PAIP2A knockout mice also showed a lowered threshold for the induction of L-LTP [39].

Mammalian target of rapamycin (mTOR) signaling regulates translational initiation and is involved in memory formation and synaptic plasticity [112,113]. Dysregulation of mTOR signaling is also associated with cognitive disorders such as tuberous sclerosis [114,115]. Several mTOR-interacting proteins can regulate this signaling pathway. Among these, FK506-binding protein 12 (FKBP12) inhibits mTOR. Accordingly, activation of mTOR signaling is enhanced in brain-specific FKBP12 knockout mice and L-LTP and contextual fear memory was enhanced in the mutants [40].

\section{Manipulating epigenetic regulations}

In addition to transcriptional and translational regulations, histone modification and DNA methylation are involved in regulating learning and synaptic plasticity. Pharmacological manipulations of histone acetylation by treating with histone deacetylase (HDAC) inhibitors have been shown to enhance memory and synaptic plasticity in both mammals and invertebrates [116,117]. In addition, reducing histone acetyltransferase activity impaired both long-term memory and LTP in mice $[118,119]$. Guan and colleagues generated both transgenic and knockout mice for different HDACs [41]. HDAC2-, but not HDAC1overexpressing mice show deficits in memory and LTP, suggesting that HDAC2 might be a major target of HDAC inhibitors associated with memory enhancement [41]. Consistently, HDAC2 knockout mice showed enhanced memory and increased LTP [41]. Chromatin immunoprecipitation experiments showed that HDAC2 is associated with genes previously known to be involved in synaptic functions such as Bdnf, Egr1, Fos, Camk2a, Creb1, Crebbp, NRXN3, and the NMDAR subunit genes [41].

\section{Manipulating microRNA biogenesis}

MicroRNAs (miRNAs) are small non-coding RNA molecules that inhibit the translation of their target mRNAs. The miRNAs regulate various cellular functions including synaptic plasticity, learning, and memory [120]. Dramatic changes in the expression of miRNA have been shown to occur in response to NMDA-dependent neuronal activation or behavioral training in contextual fear conditioning [121]. Dicer, a type III ribonuclease, is a key enzyme for generating the mature form of miRNAs. Konopka and colleagues investigated the effects of miRNA using conditional knockout mice expressing Cre recombinase, which is under the control of tamoxifen [42]. Deletion of Dicer1 in the adult brain reduced the abundance of mature miRNAs, but did not cause neuronal death or abnormalities in motor function, anxiety, or circadian rhythm, for up to 14 weeks after induction of the Dicer1 mutation. Interestingly, however, Dicer1 conditional knockout mice showed enhanced learning and memory in the Morris water maze and fear conditioning tests [42]. Dicer1 deletion also altered the morphology of dendritic spines and increased the levels of synaptic proteins related to plasticity, such as brain-derived neurotrophic factor (BDNF), AMPA receptor, post-synaptic density protein 95 (PSD-95), and matrix metalloproteinase-9 (MMP-9). These results suggest that miRNA might be another important player in memory enhancement [42].

\section{Manipulating extracellular molecules}

Long-term synaptic plasticity is accompanied by synaptic structural remodeling and, therefore, manipulating any molecules that modify synaptic structures may affect synaptic plasticity and memory. MMPs are zinc-dependent proteases that are involved in the remodeling of the pericellular environment by degrading the extracellular matrix. Overexpression of MMP-9 in the forebrain enhanced memory in the Morris water maze and the object recognition task, and LTP was also enhanced in the MMP-9 transgenic mice, demonstrating that MMP-9 is a positive regulator of LTP and memory [43].

Tissue-type plasminogen activator (tPA) is an extracellular serine protease [122]. Deletion of tPA caused deficits in L-LTP and several forms of memory [123-125]. Consistently, neuronal overexpression of tPA enhanced both LTP and hippocampus-dependent spatial memory [44]. However, the mechanism underlying enhanced memory and LTP remained unclear. It has also been reported that tPA is involved in the processing of a neurotrophic factor, brain-derived neurotrophic factor (BDNF) [126]. The overexpression of tPA may increase the production of mature BDNF, which is one of the key molecules involved in L-LTP and long-term memory $[127,128]$, with consequent enhancement of hippocampal LTP and spatial memory. 


\section{The Role of LTP in memory enhancement}

Interestingly, there are mutant mice that show enhanced LTP without changes in behavior, or even with deficits in learning and memory (Table 2). For example, PSD-95 knockout mice showed severe deficits in spatial learning and memory, whereas they showed a dramatic increase in hippocampal LTP [129]. It has been extensively debated whether LTP is both necessary and sufficient for memory storage [130]. As well as the PSD-95 knockout, the other studies summarized in Table 2 also seem to support the idea that LTP is not strongly associated with memory. This may mean that long-term synaptic plasticity such as LTP is not sufficient for long-term memory storage. So far, it is difficult to draw a firm conclusion based on the studies using mutant mice. As discussed by Neves, Cooke, and Bliss [130], in order to establish the causality of LTP for memory, one needs to design an experimental system (a mutant mouse) in which only LTP is manipulated without affecting any other biological processes. However, most of the mutant mice listed in Table 2 show other behavioral and physiological phenotypes in addition to LTP enhancement. Firstly, other synaptic structures and functions in addition to LTP are affected in the mutants. For example, deleting PSD-95 affected AMPA receptor functions [131] and dystrophin knockout altered GABAergic inhibition [132]. Secondly, genetic manipulations caused abnormalities in other physiological processes. For example, FMR2 knockout mice show increased latency to paw withdrawal in the hot-plate test, suggesting that pain perception has been altered in the mutant, which might affect the learning and memory phenotype in fear conditioning [133].

In this review, the analysis began from the perspective of enhanced learning, not from that of enhanced LTP.
As discussed above, even if LTP is enhanced by a mutation, the same genetic manipulation could cause abnormalities in other cellular processes required for normal learning and memory, which makes it more difficult to draw conclusions about the role of LTP in memory. However, a better correlation between LTP and memory was observed when LTP was analyzed in the mutants that do show memory enhancement, supporting the hypothesis that the genes and signaling pathways involved in LTP are crucial to the cellular mechanisms of memory. Moreover, bi-directional manipulations of several genes have resulted in corresponding bi-directional changes in both LTP and memory. For example, deletion of tPA in mice resulted in deficits in LTP and several forms of memory such as contextual fear conditioning, object exploration, and active avoidance tasks $[123,124]$. In contrast, transgenic expression of tPA enhanced both LTP and hippocampus-dependent spatial memory [44]. Bi-directional manipulations of memory phenotypes are highly correlated with similar changes in LTP in several mouse mutants that each carrying a different genetic mutation, suggesting that this form of synaptic plasticity does play a critical role in learning and memory. This review may support the concept that LTP enhancement is necessary for memory facilitation. Of the 47 mutants listed in Table 1, LTP has been examined in 38, and 36 of those 38 show enhanced LTP. Two mutants, the Cbl-b knockout and BEC1 knockout, demonstrated enhanced memory without an enhancement of LTP $[15,22]$, which may disprove the necessity of LTP enhancement for memory enhancement. However, there are plausible explanations for this. It is well known that there are multiple protocols for LTP induction and a particular gene might only be involved in a form of LTP

Table 2 LTP enhancement without memory enhancement

\begin{tabular}{llll}
\hline Mutant & LTP phenotypes & Memory phenotypes & Reference \\
\hline Psd-95 KO & Enhanced CA1 LTP & Impaired in MWM & [129] \\
\hline Limk-1 KO & Enhanced CA1 LTP & Normal initial learning, impaired reversal learning in MWM & [134] \\
\hline Syndecan-3 KO & Enhanced CA1 LTP & Impaired in MWM & [135] \\
\hline PTPS KO & Enhanced CA1 and CA3 LTP & Impaired in MWM, RAM & [136] \\
\hline IRSp53 KO & Enhanced CA1 LTP & Impaired in MWM, ORT & [137] \\
\hline Gial KO & Enhanced CA1 LTP & Impaired in CFC, PA, ORT; but normal in MWM & [138] \\
\hline Tropomodulin-2 KO & Enhanced CA1 LTP & Impaired in CFC, MWM & [139] \\
\hline Dystrophin KO & Enhanced CA1 LTP & Impaired in MWM, ORT & [140] \\
\hline TsC2 KO & Enhanced CA1 LTP & Impaired in MWM, CFC & [114] \\
\hline GluR2 (GluA2) KO & Enhanced CA1 LTP & Impaired in MWM & [141,142] \\
\hline Fmr2 KO & Enhanced CA1 LTP & Impaired in CFC, but normal in MWM \\
\hline dnPAK Tg & Enhanced Cortical LTP & Impaired in MWM (21 days), CFC (1 day) & [133] \\
\hline Inositol 1,4,5-triphosphate 3-kinase Kl & Enhanced CA1 LTP & No change in MWM \\
\hline KO, knockout Tg, transgenc; Kl knock-in & [143] \\
\hline
\end{tabular}

$\mathrm{KO}$, knockout; Tg, transgenic; KI, knock-in; MWM, Morris water maze; RAM, radial arm maze; ORT, object recognition test; CFC, contextual fear conditioning; PA, passive avoidance; ${ }^{*}$ impaired in contextual discrimination test. 
that is induced by a specific protocol. For example, deleting GluR-A (GluA1) caused a large deficit in the LTP induced by high frequency stimulation (100 Hz tetanus), but spared the LTP induced by a theta-burst pairing protocol $[145,146]$. Although the hippocampal LTP induced by high frequency stimuli was not enhanced in Cbl-b knockout mice, other protocols for enhancing LTP have not yet been tested in these mice [15]. Another possibility is that LTP enhancement might be observed in other brain areas of those mutants, because different brain areas are involved in different forms of memory. Interestingly, the spatial memory enhancement in Cbl-b knockout mice was more pronounced when memory was tested 45 days after training [15]. It has been shown that episodic memory is initially processed in the hippocampus and is then gradually transferred to the cortical areas for long-term storage [147]. Thus, long-term synaptic plasticity could be enhanced in cortical areas in Cbl-b knockout mice.

Neither high frequency nor theta-burst stimulation resulted in LTP enhancement in the hippocampus of BEC1 knockout mice [22]. Interestingly, prominent enhancements were observed in working memory and attention tests [22], which involve cellular mechanisms in other brain regions. Synaptic plasticity in other brain areas such as the prefrontal cortex has not yet been examined in this mutant. Therefore, the studies involving Cbl-b and BEC1 knockouts cannot necessarily disprove the necessity of LTP enhancement for memory enhancement. However, it is possible that the performance in memory tasks might be enhanced by LTP-independent mechanisms in some mutants. For example, increased attention or other physiological changes could be responsible for the enhancement of behavioral performance by $\mathrm{BEC} 1$ knockout mice in spatial and working memory tests [22].

It is worth noting that causality between a genetic manipulation and LTP enhancement is not always clear. The mechanism for each mutant summarized in this review might not be the root cause of the observed enhancements and should be regarded as tentative. For example, although the mechanism underlying memory enhancement by acute expression of p25 is categorized as altered 'excitatory synaptic transmission' (Table 1), this might not be the proximal cause for the memory enhancement. Instead, the impact of the mutation on synaptic structures, such as the increased number of spines, could be the direct cause for the enhancement [6]. It will also be necessary to investigate which stages of memory processing are facilitated by the smart mutations, and these are not clear in most cases.

\section{Potential therapeutic strategies involving memory enhancement}

Elucidating memory-enhancing mechanisms will provide valuable insights into treatment options for disorders associated with memory impairments. As discussed above, reducing HDAC activity enhances memory in normal mice [41,116]. Manipulating HDAC activity has been suggested as a potential treatment for a specific cognitive disorder. Rubinstein-Taybi syndrome (RTS) is a genetic disorder associated with intellectual disabilities and skeletal abnormalities. RTS is caused by mutations in CREB binding protein (CBP), which has histone acetyltransferase (HAT) activity. Either the heterozygous deletion of $\mathrm{Cbp}$ or the expression of a mutant CBP lacking HAT activity caused deficits in LTP and memory in mice $[119,148]$. In these mouse models of RTS, administration of the HDAC inhibitors, SAHA or TSA, significantly improved both the behavioral and physiological phenotypes $[119,148]$. There is evidence that reducing the phosphorylation level of eIF2 $\alpha$ can enhance memory in mice [26]. Interestingly, deletions of the eIF2 $\alpha$ kinases GCN2 or PERK have been shown to prevent deficits in synaptic plasticity and spatial memory in mice expressing familial Alzheimer's diseaserelated mutations in APP and PSEN1 [149]. Taken together, these data suggest that genes implicated in memory enhancement in mutant mice may be potential targets for drugs designed to improve physiological conditions and behavioral outcomes in diseased brains.

\section{Adverse effects of mutations that enhance memory}

It is important to note that unexpected and adverse behavioral effects can accompany genetic manipulations that enhance memory. For example, NR2B transgenic mice have shown enhanced chronic pain [150,151]. In addition to the hippocampus, NR2B was also overexpressed in pain-related forebrain areas of the transgenic mice, including the anterior cingulate cortex [150]. While NR2B transgenic mice and their wild-type littermates showed similar responses in an acute pain test, the NR2B transgenic mice displayed enhanced responsiveness to a peripheral injection of inflammatory stimuli that induce chronic pain, suggesting that the overexpression of NR2B in the forebrain can affect pain perception in mice [150].

Another deficit associated with memory enhancement is the loss of memory flexibility. As discussed, overexpression of $\mathrm{ACl}$ enhances memory in an object recognition test [30]. However, the AC1 transgenic animals showed slower extinction for contextual fear memory [30], suggesting that this mutant might have lost its behavioral flexibility. Memory extinction does not simply involve forgetting, but is an active learning process that is critical for behavioral adaptation [152]. Similarly, while calcineurin inhibition facilitated memory in fear conditioning and conditioned taste aversion tests, it impaired the extinction of previously formed contextual fear memory and conditioned taste aversion memory [35,153]. FKBP12 knockout mice that have shown enhanced memory in contextual fear conditioning have also displayed abnormalities in 
other behavioral tests [40]. The mutant mice showed a performance comparable to their wild-type littermates during initial learning in the water maze and Y-maze tasks. [40]. However, the knockout mice showed deficits in reversal learning, in which the mice need to learn new locations for the escape platforms [40]. Moreover, FKBP12 mutants showed a preference for the familiar object over the novel object in an object recognition test, and displayed increased repetitive behavior in a marble-burying test [40]. These findings suggest that the other smart mutants might also display unknown behavioral or physiological side-effects.

This issue will be critical when attempts are made to develop treatments for brain disorders based on memory enhancing mechanisms. It is recommended that the researchers in this field should standardize a set of rigorous behavioral tests to examine whether a memory mutant has any other behavioral and physiological phenotypes, including changes in motor function, locomotion, pain, anxiety, social behavior, and behavioral flexibilities. Unfortunately, it is not clear why some mutations have an adverse impact on behavior. It is well known that different brain areas are involved in different aspects of learning and memory. For example, different areas are involved in consolidation and extinction of fear memory [154]. Most of the genetic manipulations described in this review affect the whole body or at least the whole forebrain of the mouse. Thus, it is not surprising that a manipulation that is beneficial to one brain function could have negative effects on another. Applying more advanced genetic techniques that are region- and/or cell-specific may help in the design of smart mice with reduced risk of side-effects.

\section{Conclusions}

Genetic mutations that enhance memory in mice frequently result in a concomitant increase in LTP, suggesting that this form of synaptic plasticity plays a crucial role in learning and memory. Although there are still many issues to be addressed, it is clear that studies on the molecular and cellular mechanisms leading to enhanced memory in mutant mice have generated important insights into the pathways and mechanisms involved in plasticity and memory, which may help in the future development of broadly applicable approaches to treating neurological disorders.

\section{Abbreviations}

ATF4: Activating transcription factor 4; aCaMKII: $\mathrm{a}-\mathrm{Ca}^{2+} /$ calmodulin-dependent kinase II; BDNF: Brain-derived neurotrophic factor; CBP: CREB binding protein; Cbl-b: Casitas B-lineage lymphoma-b; Cdk5: Cyclin-dependent kinase 5; CREB: CAMP response element-binding protein; GABA: Gamma-aminobutyric acid; GCN2: General control nonderepressible 2; elF2a: Eukaryotic translation initiation factor 2 subunit a; HDAC: Histone deacetylase; LTP: Long-term potentiation; MAGL: Monoacylglycerol lipase; MAPK: Mitogen-activated protein kinase; miRNA: microRNA; MMPs: Matrix metalloproteinases; NMDAR:
N-methyl-D-aspartate receptor; ORL1: Opioid receptor-like-1; PABP. Poly (A)-binding protein; PKA: Protein kinase A; PKR: RNA-activated protein kinase; tPA: Tissue-type plasminogen activator.

\section{Competing interests}

The author declares no competing interests.

\section{Acknowledgement}

I would like to thank Dr. Bong-Kiun Kaang and Dr. Alcino Silva for their valuable discussions that shaped this review. This work was supported by Chung-Ang University Research Grants in 2013 and NRF-2013R1A3A1072570.

Received: 3 April 2014 Accepted: 27 May 2014

Published: 4 June 2014

\section{References}

1. Tang YP, Shimizu E, Dube GR, Rampon C, Kerchner GA, Zhuo M, Liu G, Tsien JZ: Genetic enhancement of learning and memory in mice. Nature 1999, 401:63-69.

2. Cao X, Cui Z, Feng R, Tang YP, Qin Z, Mei B, Tsien JZ: Maintenance of superior learning and memory function in NR2B transgenic mice during ageing. Eur J Neurosci 2007, 25:1815-1822.

3. Cui $Y$, Jin J, Zhang $X, X u$ H, Yang L, Du D, Zeng Q, Tsien JZ, Yu H, Cao X: Forebrain NR2B overexpression facilitating the prefrontal cortex long-term potentiation and enhancing working memory function in mice. PLoS One 2011, 6:e20312

4. Wang D, Cui Z, Zeng Q, Kuang H, Wang LP, Tsien JZ, Cao X: Genetic enhancement of memory and long-term potentiation but not CA1 long-term depression in NR2B transgenic rats. PLoS One 2009, 4:e7486.

5. Hawasli AH, Benavides DR, Nguyen C, Kansy JW, Hayashi K, Chambon P, Greengard P, Powell CM, Cooper DC, Bibb JA: Cyclin-dependent kinase 5 governs learning and synaptic plasticity via control of NMDAR degradation. Nat Neurosci 2007, 10:880-886.

6. Fischer A, Sananbenesi F, Pang PT, Lu B, Tsai LH: Opposing roles of transient and prolonged expression of p25 in synaptic plasticity and hippocampus-dependent memory. Neuron 2005, 48:825-838.

7. Wong RW, Setou M, Teng J, Takei Y, Hirokawa N: Overexpression of motor protein KIF17 enhances spatial and working memory in transgenic mice. Proc Natl Acad Sci U S A 2002, 99:14500-14505

8. Mamiya T, Yamada K, Miyamoto $Y$, Konig N, Watanabe $Y$, Noda $Y$, Nabeshima T: Neuronal mechanism of nociceptin-induced modulation of learning and memory: involvement of N-methyl-D-aspartate receptors. Mol Psychiatry 2003, 8:752-765.

9. Manabe T, Noda Y, Mamiya T, Katagiri H, Houtani T, Nishi M, Noda T, Takahashi T, Sugimoto T, Nabeshima T, Takeshima H: Facilitation of longterm potentiation and memory in mice lacking nociceptin receptors. Nature 1998, 394:577-581.

10. Kato T, Funakoshi H, Kadoyama K, Noma S, Kanai M, Ohya-Shimada W, Mizuno S, Doe N, Taniguchi T, Nakamura T: Hepatocyte growth factor overexpression in the nervous system enhances learning and memory performance in mice. J Neurosci Res 2012, 90:1743-1755.

11. Jeon D, Song I, Guido W, Kim K, Kim E, Oh U, Shin HS: Ablation of Ca2+ channel beta3 subunit leads to enhanced N-methyl-D-aspartate receptor-dependent long term potentiation and improved long term memory. J Biol Chem 2008, 283:12093-12101.

12. Maekawa M, Watanabe M, Yamaguchi S, Konno R, Hori Y: Spatial learning and long-term potentiation of mutant mice lacking D-amino-acid oxidase. Neurosci Res 2005, 53:34-38.

13. Kushner SA, Elgersma $Y$, Murphy GG, Jaarsma D, van Woerden GM, Hojjati MR, Cui Y, LeBoutillier JC, Marrone DF, Choi ES, De Zeeuw Cl, Petit TL, Pozzo-Miller L, Silva AJ: Modulation of presynaptic plasticity and learning by the $\mathrm{H}$-ras/extracellular signal-regulated kinase/synapsin I signaling pathway. The Journal of neuroscience : the official journal of the Society for Neuroscience 2005, 25:9721-9734.

14. Jeon D, Yang YM, Jeong MJ, Philipson KD, Rhim H, Shin HS: Enhanced learning and memory in mice lacking $\mathrm{Na}+/ \mathrm{Ca} 2+$ exchanger 2. Neuron 2003, 38:965-976. 
15. Tan DP, Liu QY, Koshiya N, Gu H, Alkon D: Enhancement of long-term memory retention and short-term synaptic plasticity in cbl-b null mice. Proc Natl Acad Sci U S A 2006, 103:5125-5130.

16. Routtenberg A, Cantallops I, Zaffuto S, Serrano P, Namgung U: Enhanced learning after genetic overexpression of a brain growth protein. Proc Nat/ Acad Sci U S A 2000, 97:7657-7662.

17. Moore MD, Cushman J, Chandra D, Homanics GE, Olsen RW, Fanselow MS: Trace and contextual fear conditioning is enhanced in mice lacking the alpha4 subunit of the GABA (A) receptor. Neurobiol Learn Mem 2010, 93:383-387.

18. Pan B, Wang W, Zhong P, Blankman JL, Cravatt BF, Liu QS: Alterations of endocannabinoid signaling, synaptic plasticity, learning, and memory in monoacylglycerol lipase knock-out mice. J Neurosci 2011, 31:13420-13430.

19. Zhu PJ, Huang W, Kalikulov D, Yoo JW, Placzek AN, Stoica L, Zhou H, Bell JC, Friedlander MJ, Krnjevic K, Noebels JL, Costa-Mattioli M: Suppression of PKR promotes network excitability and enhanced cognition by interferon-gamma-mediated disinhibition. Cell 2011, 147:1384-1396.

20. Collinson N, Kuenzi FM, Jarolimek W, Maubach KA, Cothliff R, Sur C, Smith A, Otu FM, Howell O, Atack JR, McKernan RM, Seabrook GR, Dawson GR, Whiting PJ, Rosahl TW: Enhanced learning and memory and altered GABAergic synaptic transmission in mice lacking the alpha 5 subunit of the GABA (A) receptor. J Neurosci 2002, 22:5572-5580.

21. Shumyatsky GP, Tsvetkov E, Malleret G, Vronskaya S, Hatton M, Hampton L, Battey JF, Dulac C, Kandel ER, Bolshakov VY: Identification of a signaling network in lateral nucleus of amygdala important for inhibiting memory specifically related to learned fear. Cell 2002, 111:905-918.

22. Miyake A, Takahashi S, Nakamura Y, Inamura K, Matsumoto S, Mochizuki S, Katou M: Disruption of the ether-a-go-go $\mathrm{K}+$ channel gene $\mathrm{BEC} 1 / \mathrm{KCNH} 3$ enhances cognitive function. J Neurosci 2009, 29:14637-14645.

23. Murphy GG, Fedorov NB, Giese KP, Ohno M, Friedman E, Chen R, Silva AJ: Increased neuronal excitability, synaptic plasticity, and learning in aged Kvbeta1.1 knockout mice. Curr Biol 2004, 14:1907-1915.

24. Nolan MF, Malleret G, Dudman JT, Buhl DL, Santoro B, Gibbs E, Vronskaya S, Buzsaki G, Siegelbaum SA, Kandel ER, Morozov A: A behavioral role for dendritic integration: HCN1 channels constrain spatial memory and plasticity at inputs to distal dendrites of CA1 pyramidal neurons. Cell 2004, 119:719-732.

25. Suzuki A, Fukushima $H$, Mukawa T, Toyoda $H$, Wu L, Zhao MG, Xu H, Shang Y, Endoh K, Iwamoto T, Mamiya N, Okano E, Hasegawa S, Mercaldo V, Zhang Y, Maeda R, Ohta M, Josselyn SA, Zhuo M, Kida S: Upregulation of CREB-mediated transcription enhances both short- and long-term memory. J Neurosci 2011, 31:8786-8802.

26. Costa-Mattioli M, Gobert D, Stern E, Gamache K, Colina R, Cuello C, Sossin W, Kaufman R, Pelletier J, Rosenblum K, Krnjevic K, Lacaille JC, Nader K, Sonenberg N: elF2alpha phosphorylation bidirectionally regulates the switch from short- to long-term synaptic plasticity and memory. Cell 2007, 129:195-206.

27. Costa-Mattioli M, Gobert D, Harding H, Herdy B, Azzi M, Bruno M, Bidinosti M, Ben Mamou C, Marcinkiewicz E, Yoshida M, Imataka H, Cuello AC, Seidah N, Sossin W, Lacaille JC, Ron D, Nader K, Sonenberg N: Translational control of hippocampal synaptic plasticity and memory by the elF2alpha kinase GCN2. Nature 2005, 436:1166-1173.

28. Chen A, Muzzio IA, Malleret G, Bartsch D, Verbitsky M, Pavlidis P, Yonan AL, Vronskaya S, Grody MB, Cepeda I, Gilliam TC, Kandel ER: Inducible enhancement of memory storage and synaptic plasticity in transgenic mice expressing an inhibitor of ATF4 (CREB-2) and C/EBP proteins. Neuron 2003, 39:655-669.

29. Fukushima H, Maeda R, Suzuki R, Suzuki A, Nomoto M, Toyoda H, Wu LJ, Xu H, Zhao MG, Ueda K, Kitamoto A, Mamiya N, Yoshida T, Homma S, Masushige S, Zhuo M, Kida S: Upregulation of calcium/calmodulin-dependent protein kinase IV improves memory formation and rescues memory loss with aging. J Neurosci 2008, 28:9910-9919.

30. Wang $H$, Ferguson GD, Pineda W, Cundiff PE, Storm DR: Overexpression of type-1 adenylyl cyclase in mouse forebrain enhances recognition memory and LTP. Nat Neurosci 2004, 7:635-642.

31. Isiegas C, McDonough C, Huang T, Havekes R, Fabian S, Wu L, Xu H, Zhao MG, Kim Jl, Lee YS, Lee HR, Ko HG, Lee N, Choi SL, Lee JS, Son H, Zhuo M, Kaang BK, Abel T: A novel conditional genetic system reveals that increasing neuronal CAMP enhances memory and retrieval. J Neurosci 2008, 28:6220-6230
32. Rutten K, Misner DL, Works M, Blokland A, Novak TJ, Santarelli L, Wallace TL: Enhanced long-term potentiation and impaired learning in phosphodiesterase 4D-knockout (PDE4D) mice. Eur J Neurosci 2008 28:625-632.

33. Li YF, Cheng YF, Huang Y, Conti M, Wilson SP, O'Donnell JM, Zhang HT: Phosphodiesterase-4D knock-out and RNA interference-mediated knock-down enhance memory and increase hippocampal neurogenesis via increased cAMP signaling. J Neurosci 2011, 31:172-183.

34. Tsai LC, Chan GC, Nangle SN, Shimizu-Albergine M, Jones GL, Storm DR, Beavo JA, Zweifel LS: Inactivation of Pde8b enhances memory, motor performance, and protects against age-induced motor coordination decay. Genes Brain Behav 2012, 11:837-847.

35. Baumgartel K, Genoux D, Welzl H, Tweedie-Cullen RY, Koshibu K, Livingstone-Zatchej M, Mamie C, Mansuy IM: Control of the establishment of aversive memory by calcineurin and Zif268. Nat Neurosci 2008, 11:572-578.

36. Malleret G, Haditsch U, Genoux D, Jones MW, Bliss TV, Vanhoose AM, Weitlauf C, Kandel ER, Winder DG, Mansuy IM: Inducible and reversible enhancement of learning, memory, and long-term potentiation by genetic inhibition of calcineurin. Cell 2001, 104:675-686.

37. Genoux D, Haditsch U, Knobloch M, Michalon A, Storm D, Mansuy IM: Protein phosphatase 1 is a molecular constraint on learning and memory. Nature 2002, 418:970-975.

38. Jouvenceau A, Hedou G, Potier B, Kollen M, Dutar P, Mansuy IM: Partial inhibition of PP1 alters bidirectional synaptic plasticity in the hippocampus. Eur J Neurosci 2006, 24:564-572.

39. Khoutorsky A, Yanagiya A, Gkogkas CG, Fabian MR, Prager-Khoutorsky M, Cao R, Gamache K, Bouthiette F, Parsyan A, Sorge RE, Mogil JS, Nader K, Lacaille JC, Sonenberg N: Control of synaptic plasticity and memory via suppression of poly (A)-binding protein. Neuron 2013, 78:298-311.

40. Hoeffer CA, Tang W, Wong H, Santillan A, Patterson RJ, Martinez LA, Tejada-Simon MV, Paylor R, Hamilton SL, Klann E: Removal of FKBP12 enhances mTOR-Raptor interactions, LTP, memory, and perseverative/ repetitive behavior. Neuron 2008, 60:832-845.

41. Guan JS, Haggarty SJ, Giacometti E, Dannenberg JH, Joseph N, Gao J, Nieland TJ, Zhou Y, Wang X, Mazitschek R, Bradner JE, DePinho RA, Jaenisch $\mathrm{R}$, Tsai LH: HDAC2 negatively regulates memory formation and synaptic plasticity. Nature 2009, 459:55-60

42. Konopka W, Kiryk A, Novak M, Herwerth M, Parkitna JR, Wawrzyniak M, Kowarsch A, Michaluk P, Dzwonek J, Arnsperger T, Wilczynski G, Merkenschlager M, Theis FJ, Kohr G, Kaczmarek L, Schutz G: MicroRNA loss enhances learning and memory in mice. J Neurosci 2010, 30:14835-14842.

43. Fragkouli A, Papatheodoropoulos C, Georgopoulos S, Stamatakis A, Stylianopoulou F, Tsilibary EC, Tzinia AK: Enhanced neuronal plasticity and elevated endogenous sAPPalpha levels in mice over-expressing MMP9. J Neurochem 2012, 121:239-251.

44. Madani R, Hulo S, Toni N, Madani H, Steimer T, Muller D, Vassalli JD: Enhanced hippocampal long-term potentiation and learning by increased neuronal expression of tissue-type plasminogen activator in transgenic mice. EMBO J 1999, 18:3007-3012.

45. Pavlov I, Voikar V, Kaksonen M, Lauri SE, Hienola A, Taira T, Rauvala H: Role of heparin-binding growth-associated molecule (HB-GAM) in hippocampal LTP and spatial learning revealed by studies on overexpressing and knockout mice. Mol Cell Neurosci 2002, 20:330-342.

46. Pavlov I, Rauvala H, Taira T: Enhanced hippocampal GABAergic inhibition in mice overexpressing heparin-binding growth-associated molecule. Neuroscience 2006, 139:505-511.

47. Saab BJ, Georgiou J, Nath A, Lee FJ, Wang M, Michalon A, Liu F, Mansuy IM, Roder JC: NCS-1 in the dentate gyrus promotes exploration, synaptic plasticity, and rapid acquisition of spatial memory. Neuron 2009, 63:643-656

48. Lee SE, Simons SB, Heldt SA, Zhao M, Schroeder JP, Vellano CP, Cowan DP, Ramineni S, Yates CK, Feng Y, Smith Y, Sweatt JD, Weinshenker D, Ressler KJ, Dudek SM, Hepler JR: RGS14 is a natural suppressor of both synaptic plasticity in CA2 neurons and hippocampal-based learning and memory. Proc Natl Acad Sci U S A 2010, 107:16994-16998.

49. Harrell AV, Allan AM: Improvements in hippocampal-dependent learning and decremental attention in 5-HT (3) receptor overexpressing mice. Learn Mem 2003, 10:410-419.

50. Kim JJ, Shih JC, Chen K, Chen L, Bao S, Maren S, Anagnostaras SG, Fanselow MS, De Maeyer E, Seif I, Thompson RF: Selective enhancement of 
emotional, but not motor, learning in monoamine oxidase A-deficient mice. Proc Natl Acad Sci U S A 1997, 94:5929-5933.

51. Dere E, De Souza-Silva MA, Topic B, Spieler RE, Haas HL, Huston JP: Histidine-decarboxylase knockout mice show deficient nonreinforced episodic object memory, improved negatively reinforced water-maze performance, and increased neo- and ventro-striatal dopamine turnover. Learn Mem 2003, 10:510-519.

52. Liu L, Zhang S, Zhu Y, Fu Q, Zhu Y, Gong Y, Ohtsu H, Luo J, Wei E, Chen Z: Improved learning and memory of contextual fear conditioning and hippocampal CA1 long-term potentiation in histidine decarboxylase knock-out mice. Hippocampus 2007, 17:634-641.

53. Slane JM, Lee HS, Vorhees CV, Zhang JH, Xu M: DNA fragmentation factor 45 deficient mice exhibit enhanced spatial learning and memory compared to wild-type control mice. Brain Res 2000, 867:70-79.

54. McQuade JM, Vorhees CV, Xu M, Zhang JH: DNA fragmentation factor 45 knockout mice exhibit longer memory retention in the novel object recognition task compared to wild-type mice. Physiol Behav 2002, 76:315-320

55. Hu D, Serrano F, Oury TD, Klann E: Aging-dependent alterations in synaptic plasticity and memory in mice that overexpress extracellular superoxide dismutase. J Neurosci 2006, 26:3933-3941.

56. Nishiyama H, Knopfel T, Endo S, Itohara S: Glial protein S100B modulates long-term neuronal synaptic plasticity. Proc Natl Acad Sci U S A 2002, 99:4037-4042

57. Bliss TV, Gardner-Medwin AR: Long-lasting potentiation of synaptic transmission in the dentate area of the unanaestetized rabbit following stimulation of the perforant path. J Physiol 1973, 232:357-374.

58. Bliss TV, Lømo T: Long-lasting potentiation of synaptic transmission in the dentate area of the anaesthetized rabbit following stimulation of the perforant path. J Physiol 1973, 232:331-356.

59. Malenka RC, Nicoll RA: Long-term potentiation-a decade of progress? Science 1999, 285:1870-1874.

60. Matynia A, Kushner SA, Silva AJ: Genetic approaches to molecular and cellular cognition: a focus on LTP and learning and memory. Annu Rev Genet 2002, 36:687-720.

61. Eichenbaum H: Learning from LTP: a comment on recent attempts to identify cellular and molecular mechanisms of memory. Learn Mem 1996, 3:61-73

62. Silva AJ: Molecular and cellular cognitive studies of the role of synaptic plasticity in memory. J Neurobiol 2003, 54:224-237.

63. Bliss TV, Collingridge GL: A synaptic model of memory: long-term potentiation in the hippocampus. Nature 1993, 361:31-39.

64. Whitlock JR, Heynen AJ, Shuler MG, Bear MF: Learning induces long-term potentiation in the hippocampus. Science 2006, 313:1093-1097.

65. Rogan MT, Staubli UV, LeDoux JE: Fear conditioning induces associative long-term potentiation in the amygdala. Nature 1997, 390:604-607.

66. McKernan MG, Shinnick-Gallagher P: Fear conditioning induces a lasting potentiation of synaptic currents in vitro. Nature 1997, 390:607-611.

67. Monyer $\mathrm{H}$, Sprengel $\mathrm{R}$, Schoepfer $\mathrm{R}$, Herb A, Higuchi M, Lomeli H, Burnashev N, Sakmann B, Seeburg PH: Heteromeric NMDA receptors: molecular and functional distinction of subtypes. Science 1992, 256:1217-1221.

68. Sanes JR, Lichtman JW: Can molecules explain long-term potentiation? Nat Neurosci 1999, 2:597-604

69. Lisman J, Schulman $\mathrm{H}$, Cline $\mathrm{H}$ : The molecular basis of CaMKII function in synaptic and behavioural memory. Nat Rev Neurosci 2002, 3:175-190

70. Sheng M, Cummings J, Roldan LA, Jan YN, Jan LY: Changing subunit composition of heteromeric NMDA receptors during development of rat cortex. Nature 1994, 368:144-147.

71. Monyer H, Burnashev N, Laurie DJ, Sakmann B, Seeburg PH: Developmental and regional expression in the rat brain and functional properties of four NMDA receptors. Neuron 1994, 12:529-540.

72. Morris RG, Anderson E, Lynch GS, Baudry M: Selective impairment of learning and blockade of long-term potentiation by an N-methyl-D-aspartate receptor antagonist, AP5. Nature 1986, 319:774-776.

73. Tsien JZ, Huerta PT, Tonegawa S: The essential role of hippocampal CA1 NMDA receptor-dependent synaptic plasticity in spatial memory. Cell 1996, 87:1327-1338

74. McHugh TJ, Jones MW, Quinn JJ, Balthasar N, Coppari R, Elmquist JK, Lowell BB, Fanselow MS, Wilson MA, Tonegawa S: Dentate gyrus NMDA receptors mediate rapid pattern separation in the hippocampal network. Science 2007, 317:94-99.

75. Nakazawa K, Sun LD, Quirk MC, Rondi-Reig L, Wilson MA, Tonegawa S: Hippocampal CA3 NMDA receptors are crucial for memory acquisition of one-time experience. Neuron 2003, 38:305-315.

76. Nakazawa K, Quirk MC, Chitwood RA, Watanabe M, Yeckel MF, Sun LD, Kato A, Carr CA, Johnston D, Wilson MA, Tonegawa S: Requirement for hippocampal CA3 NMDA receptors in associative memory recall. Science 2002, 297:211-218.

77. Kiyama Y, Manabe T, Sakimura K, Kawakami F, Mori H, Mishina M: Increased thresholds for long-term potentiation and contextual learning in mice lacking the NMDA-type glutamate receptor epsilon1 subunit. J Neurosci 1998, 18:6704-6712

78. Sakimura K, Kutsuwada T, Ito I, Manabe T, Takayama C, Kushiya E, Yagi T, Aizawa S, Inoue Y, Sugiyama H, Mishina M: Reduced hippocampal LTP and spatial learning in mice lacking NMDA receptor epsilon 1 subunit. Nature 1995, 373:151-155.

79. Morris RG, Garrud P, Rawlins JN, O'Keefe J: Place navigation impaired in rats with hippocampal lesions. Nature 1982, 297:681-683.

80. Setou M, Nakagawa T, Seog DH, Hirokawa N: Kinesin superfamily motor protein KIF17 and mLin-10 in NMDA receptor-containing vesicle transport. Science 2000, 288:1796-1802.

81. Husi H, Ward MA, Choudhary JS, Blackstock WP, Grant SG: Proteomic analysis of NMDA receptor-adhesion protein signaling complexes. Nat Neurosci 2000, 3:661-669.

82. Simpkins KL, Guttmann RP, Dong Y, Chen Z, Sokol S, Neumar RW, Lynch DR: Selective activation induced cleavage of the NR2B subunit by calpain. J Neurosci 2003, 23:11322-11331.

83. Plattner F, Hernandez A, Kistler TM, Pozo K, Zhong P, Yuen EY, Tan C, Hawasli AH, Cooke SF, Nishi A, Guo A, Wiederhold T, Yan Z, Bibb JA: Memory enhancement by targeting $\mathrm{Cdk} 5$ regulation of NR2B. Neuron 2014, 81:1070-1083.

84. Cruz JC, Tseng HC, Goldman JA, Shih H, Tsai LH: Aberrant Cdk5 activation by 225 triggers pathological events leading to neurodegeneration and neurofibrillary tangles. Neuron 2003, 40:471-483.

85. Henderson G, McKnight AT: The orphan opioid receptor and its endogenous ligand-nociceptin/orphanin FQ. Trends Pharmacol Sci 1997, 18:293-300.

86. Kaneko M, Cheetham CE, Lee YS, Silva AJ, Stryker MP, Fox K: Constitutively active $\mathrm{H}$-ras accelerates multiple forms of plasticity in developing visual cortex. Proc Natl Acad Sci U S A 2010, 107:19026-19031.

87. Cui Y, Costa RM, Murphy GG, Elgersma Y, Zhu Y, Gutmann DH, Parada LF, Mody I, Silva AJ: Neurofibromin regulation of ERK signaling modulates GABA release and learning. Cell 2008, 135:549-560.

88. Lee YS, Silva AJ: Modeling hyperactivity: of mice and men. Nat Med 2011 17:541-542.

89. Shilyansky C, Lee YS, Silva AJ: Molecular and cellular mechanisms of learning disabilities: a focus on NF1. Annu Rev Neurosci 2010, 33:221-243.

90. Izquierdo I, Medina JH: GABAA receptor modulation of memory: the role of endogenous benzodiazepines. Trends Pharmacol Sci 1991, 12:260-265.

91. McGaugh $J$, Roozendaal B: Drug enhancement of memory consolidation: historical perspective and neurobiological implications. Psychopharmacology (Berl) 2009, 202:3-14.

92. Abraham WC, Gustafsson B, Wigstrom $\mathrm{H}$ : Single high strength afferent volleys can produce long-term potentiation in the hippocampus in vitro. Neurosci Lett 1986, 70:217-222.

93. Muller M, Fontana A, Zbinden G, Gahwiler BH: Effects of interferons and hydrogen peroxide on CA3 pyramidal cells in rat hippocampal slice cultures. Brain Res 1993, 619:157-162.

94. Kim H, Lee SH, Han JH, Lee JA, Cheang YH, Chang DJ, Lee YS, Kaang BK: A nucleolar protein ApLLP induces ApC/EBP expression required for long-term synaptic facilitation in aplysia neurons. Neuron 2006, 49:707-718.

95. Lee JA, Kim HK, Kim KH, Han JH, Lee YS, Lim CS, Chang DJ, Kubo T, Kaang BK: Overexpression of and RNA interference with the CCAAT enhancer-binding protein on long-term facilitation of Aplysia sensory to motor synapses. Learn Mem 2001, 8:220-226.

96. Bourtchuladze R, Frenguelli B, Blendy J, Cioffi D, Schutz G, Silva AJ: Deficient long-term memory in mice with a targeted mutation of the cAMP-responsive element-binding protein. Cell 1994, 79:59-68.

97. Yin JC, Wallach JS, Del Vecchio M, Wilder EL, Zhou H, Quinn WG, Tully T: Induction of a dominant negative CREB transgene specifically blocks long-term memory in Drosophila. Cell 1994, 79:49-58. 
98. Bartsch D, Casadio A, Karl KA, Serodio P, Kandel ER: CREB1 encodes a nuclear activator, a repressor, and a cytoplasmic modulator that form a regulatory unit critical for long-term facilitation. Cell 1998, 95:211-223.

99. Kandel ER: The molecular biology of memory storage: a dialogue between genes and synapses. Science 2001, 294:1030-1038.

100. Silva AJ, Kogan JH, Frankland PW, Kida S: CREB and memory. Annu Rev Neurosci 1998, 21:127-148.

101. Kida S, Josselyn SA, de Ortiz SP, Kogan JH, Chevere I, Masushige S, Silva AJ: CREB required for the stability of new and reactivated fear memories. Nat Neurosci 2002, 5:348-355.

102. Lee YS, Bailey CH, Kandel ER, Kaang BK: Transcriptional regulation of longterm memory in the marine snail Aplysia. Mol Brain 2008, 1:3.

103. Barco A, Alarcon JM, Kandel ER: Expression of constitutively active CREB protein facilitates the late phase of long-term potentiation by enhancing synaptic capture. Cell 2002, 108:689-703.

104. Shaywitz AJ, Greenberg ME: CREB: a stimulus-induced transcription factor activated by a diverse array of extracellular signals. Annu Rev Biochem 1999, 68:821-861.

105. Bartsch D, Ghirardi M, Skehel PA, Karl KA, Herder SP, Chen M, Bailey CH, Kandel ER: Aplysia CREB2 represses long-term facilitation: relief of repression converts transient facilitation into long-term functional and structural change. Cell 1995, 83:979-992.

106. Lee JA, Kim H, Lee YS, Kaang BK: Overexpression and RNA interference of Ap-cyclic AMP-response element binding protein-2, a repressor of long-term facilitation, in Aplysia kurodai sensory-to-motor synapses. Neurosci Lett 2003, 337:9-12.

107. Karpinski BA, Morle GD, Huggenvik J, Uhler MD, Leiden JM: Molecular cloning of human CREB-2: an ATF/CREB transcription factor that can negatively regulate transcription from the CAMP response element. Proc Natl Acad Sci U S A 1992, 89:4820-4824.

108. Harding HP, Novoa I, Zhang Y, Zeng H, Wek R, Schapira M, Ron D: Regulated translation initiation controls stress-induced gene expression in mammalian cells. Mol Cell 2000, 6:1099-1108.

109. Sonenberg N, Dever TE: Eukaryotic translation initiation factors and regulators. Curr Opin Struct Biol 2003, 13:56-63.

110. Wong ST, Athos J, Figueroa XA, Pineda W, Schaefer ML, Chavkin CC, Muglia $\sqcup$, Storm DR: Calcium-stimulated adenylyl cyclase activity is critical for hippocampus-dependent long-term memory and late phase LTP. Neuron 1999, 23:787-798.

111. Chang DJ, Li XC, Lee YS, Kim HK, Kim US, Cho NJ, Lo X, Weiss KR, Kandel ER, Kaang BK: Activation of a heterologously expressed octopamine receptor coupled only to adenylyl cyclase produces all the features of presynaptic facilitation in aplysia sensory neurons. Proc Natl Acad Sci U S A 2000, 97:1829-1834.

112. Bekinschtein P, Katche C, Slipczuk LN, Igaz LM, Cammarota M, Izquierdo I, Medina JH: mTOR signaling in the hippocampus is necessary for memory formation. Neurobiol Learn Mem 2007, 87:303-307.

113. Tang SJ, Reis G, Kang H, Gingras AC, Sonenberg N, Schuman EM: A rapamycin-sensitive signaling pathway contributes to long-term synaptic plasticity in the hippocampus. Proc Natl Acad Sci U S A 2002, 99:467-472.

114. Ehninger D, Han S, Shilyansky C, Zhou Y, Li W, Kwiatkowski DJ, Ramesh V, Silva AJ: Reversal of learning deficits in a Tsc2 (+/-) mouse model of tuberous sclerosis. Nat Med 2008, 14:843-848.

115. Krab LC, Goorden SM, Elgersma Y: Oncogenes on my mind: ERK and MTOR signaling in cognitive diseases. Trends Genet 2008, 24:498-510.

116. Levenson JM, Sweatt JD: Epigenetic mechanisms in memory formation. Nat Rev Neurosci 2005, 6:108-118.

117. Si K, Lindquist S, Kandel E: A possible epigenetic mechanism for the persistence of memory. Cold Spring Harb Symp Quant Biol 2004, 69:497-498.

118. Bourtchouladze R, Lidge R, Catapano R, Stanley J, Gossweiler S, Romashko $D$, Scott R, Tully T: A mouse model of Rubinstein-Taybi syndrome: defective long-term memory is ameliorated by inhibitors of phosphodiesterase 4. Proc Natl Acad Sci U S A 2003, 100:10518-10522.

119. Korzus E, Rosenfeld MG, Mayford M: CBP histone acetyltransferase activity is a critical component of memory consolidation. Neuron 2004, 42:961-972

120. Kosik KS: The neuronal microRNA system. Nat Rev Neurosci 2006, 7:911-920.

121. Kye MJ, Neveu P, Lee YS, Zhou M, Steen JA, Sahin M, Kosik KS, Silva AJ: NMDA mediated contextual conditioning changes miRNA expression. PLoS One 2011, 6:e24682
122. Qian Z, Gilbert ME, Colicos MA, Kandel ER, Kuhl D: Tissue-plasminogen activator is induced as an immediate-early gene during seizure, kindling and long-term potentiation. Nature 1993, 361:453-457.

123. Huang YY, Bach ME, Lipp HP, Zhuo M, Wolfer DP, Hawkins RD, Schoonjans L, Kandel ER, Godfraind JM, Mulligan R, Collen D, Carmeliet P: Mice lacking the gene encoding tissue-type plasminogen activator show a selective interference with late-phase long-term potentiation in both Schaffer collateral and mossy fiber pathways. Proc Natl Acad Sci U S A 1996 93:8699-8704

124. Calabresi P, Napolitano M, Centonze D, Marfia GA, Gubellini P, Teule MA, Berretta N, Bernardi G, Frati L, Tolu M, Gulino A: Tissue plasminogen activator controls multiple forms of synaptic plasticity and memory. Eur J Neurosci 2000, 12:1002-1012.

125. Carmeliet $P$, Schoonjans L, Kieckens L, Ream B, Degen J, Bronson R, De Vos $\mathrm{R}$, van den Oord JJ, Collen D, Mulligan RC: Physiological consequences of loss of plasminogen activator gene function in mice. Nature 1994, 368:419-424.

126. Pang PT, Teng HK, Zaitsev E, Woo NT, Sakata K, Zhen S, Teng KK, Yung WH, Hempstead BL, Lu B: Cleavage of proBDNF by tPA/plasmin is essential for long-term hippocampal plasticity. Science 2004, 306:487-491.

127. Pang PT, Lu B: Regulation of late-phase LTP and long-term memory in normal and aging hippocampus: role of secreted proteins TPA and BDNF. Ageing Res Rev 2004, 3:407-430.

128. Nagappan G, Lu B: Activity-dependent modulation of the BDNF receptor TrkB: mechanisms and implications. Trends Neurosci 2005, 28:464-471.

129. Migaud M, Charlesworth P, Dempster M, Webster LC, Watabe AM, Makhinson M, He Y, Ramsay MF, Morris RG, Morrison JH, O'Dell TJ, Grant SG: Enhanced long-term potentiation and impaired learning in mice with mutant postsynaptic density-95 protein. Nature 1998, 396:433-439.

130. Neves G, Cooke SF, Bliss TV: Synaptic plasticity, memory and the hippocampus: a neural network approach to causality. Nat Rev Neurosci 2008, 9:65-75.

131. Beique JC, Lin DT, Kang MG, Aizawa H, Takamiya K, Huganir RL: Synapse-specific regulation of AMPA receptor function by PSD-95. Proc Natl Acad Sci U S A 2006, 103:19535-19540.

132. Knuesel I, Mastrocola M, Zuellig RA, Bornhauser B, Schaub MC, Fritschy JM: Short communication: altered synaptic clustering of GABAA receptors in mice lacking dystrophin (mdx mice). Eur J Neurosci 1999, 11:4457-4462

133. Gu Y, Mcllwain KL, Weeber EJ, Yamagata T, Xu B, Antalffy BA, Reyes C, Yuva-Paylor L, Armstrong D, Zoghbi H, Sweatt JD, Paylor R, Nelson DL: Impaired conditioned fear and enhanced long-term potentiation in Fmr2 knock-out mice. J Neurosci 2002, 22:2753-2763.

134. Meng Y, Zhang Y, Tregoubov V, Janus C, Cruz L, Jackson M, Lu WY, MacDonald JF, Wang JY, Falls DL, Jia Z: Abnormal spine morphology and enhanced LTP in LIMK-1 knockout mice. Neuron 2002, 35:121-133.

135. Kaksonen M, Pavlov I, Voikar V, Lauri SE, Hienola A, Riekki R, Lakso M, Taira T, Rauvala H: Syndecan-3-deficient mice exhibit enhanced LTP and impaired hippocampus-dependent memory. Mol Cell Neurosci 2002, 21:158-172.

136. Uetani N, Kato K, Ogura H, Mizuno K, Kawano K, Mikoshiba K, Yakura H, Asano M, Iwakura Y: Impaired learning with enhanced hippocampal longterm potentiation in PTPdelta-deficient mice. EMBO J 2000, 19:2775-2785.

137. Kim MH, Choi J, Yang J, Chung W, Kim JH, Paik SK, Kim K, Han S, Won H, Bae YS, Cho SH, Seo J, Bae YC, Choi SY, Kim E: Enhanced NMDA receptor-mediated synaptic transmission, enhanced long-term potentiation, and impaired learning and memory in mice lacking IRSp53. J Neurosci 2009, 29:1586-1595.

138. Pineda W, Athos Jl, Wang H, Celver J, Ippolito D, Boulay G, Birnbaumer L, Storm DR: Removal of G (ialpha1) constraints on adenylyl cyclase in the hippocampus enhances LTP and impairs memory formation. Neuron 2004, 41:153-163.

139. Cox PR, Fowler V, Xu B, Sweatt JD, Paylor R, Zoghbi HY: Mice lacking Tropomodulin-2 show enhanced long-term potentiation, hyperactivity, and deficits in learning and memory. Mol Cell Neurosci 2003, 23:1-12

140. Vaillend C, Billard JM, Laroche S: Impaired long-term spatial and recognition memory and enhanced CA1 hippocampal LTP in the dystrophin-deficient Dmd (mdx) mouse. Neurobiol Dis 2004, 17:10-20.

141. Gerlai R, Henderson JT, Roder JC, Jia Z: Multiple behavioral anomalies in GluR2 mutant mice exhibiting enhanced LTP. Behav Brain Res 1998, 95:37-45. 
142. Jia Z, Agopyan N, Miu P, Xiong Z, Henderson J, Gerlai R, Taverna FA, Velumian A, MacDonald J, Carlen P, Abramow-Newerly W, Roder J: Enhanced LTP in mice deficient in the AMPA receptor GluR2. Neuron 1996, 17:945-956.

143. Hayashi ML, Choi SY, Rao BS, Jung HY, Lee HK, Zhang D, Chattarji S, Kirkwood A, Tonegawa S: Altered cortical synaptic morphology and impaired memory consolidation in forebrain- specific dominant-negative PAK transgenic mice. Neuron 2004, 42:773-787.

144. Jun K, Choi G, Yang SG, Choi KY, Kim H, Chan GC, Storm DR, Albert C, Mayr GW, Lee CJ, Shin HS: Enhanced hippocampal CA1 LTP but normal spatial learning in inositol 1,4,5-trisphosphate 3-kinase (A)-deficient mice. Learn Mem 1998, 5:317-330.

145. Hoffman DA, Sprengel R, Sakmann B: Molecular dissection of hippocampal theta-burst pairing potentiation. Proc Natl Acad Sci U S A 2002, 99:7740-7745.

146. Zamanillo D, Sprengel R, Hvalby O, Jensen V, Burnashev N, Rozov A, Kaiser KM, Koster HJ, Borchardt T, Worley P, Lubke J, Frotscher M, Kelly PH, Sommer B, Andersen P, Seeburg PH, Sakmann B: Importance of AMPA receptors for hippocampal synaptic plasticity but not for spatial learning. Science 1999, 284:1805-1811.

147. Wiltgen BJ, Brown RA, Talton LE, Silva AJ: New circuits for old memories: the role of the neocortex in consolidation. Neuron 2004, 44:101-108.

148. Alarcon JM, Malleret G, Touzani K, Vronskaya S, Ishii S, Kandel ER, Barco A: Chromatin acetylation, memory, and LTP are impaired in CBP+/- mice: a model for the cognitive deficit in Rubinstein-Taybi syndrome and its amelioration. Neuron 2004, 42:947-959.

149. Ma T, Trinh MA, Wexler AJ, Bourbon C, Gatti E, Pierre P, Cavener DR, Klann E: Suppression of elF2alpha kinases alleviates Alzheimer's disease-related plasticity and memory deficits. Nat Neurosci 2013, 16:1299-1305.

150. Wei F, Wang GD, Kerchner GA, Kim SJ, Xu HM, Chen ZF, Zhuo M: Genetic enhancement of inflammatory pain by forebrain NR2B overexpression. Nat Neurosci 2001, 4:164-169.

151. Zhuo M: Plasticity of NMDA receptor NR2B subunit in memory and chronic pain. Mol Brain 2009, 2:4

152. Phelps EA, Delgado MR, Nearing KI, LeDoux JE: Extinction learning in humans: role of the amygdala and vmPFC. Neuron 2004, 43:897-905

153. Havekes R, Nijholt IM, Visser AK, Eisel UL, Van der Zee EA: Transgenic inhibition of neuronal calcineurin activity in the forebrain facilitates fear conditioning, but inhibits the extinction of contextual fear memories. Neurobiol Learn Mem 2008, 89:595-598.

154. Myers KM, Davis M: Behavioral and neural analysis of extinction. Neuron 2002, 36:567-584.

doi:10.1186/1756-6606-7-43

Cite this article as: Lee: Genes and signaling pathways involved in memory enhancement in mutant mice. Molecular Brain 2014 7:43.

\section{Submit your next manuscript to BioMed Central and take full advantage of:}

- Convenient online submission

- Thorough peer review

- No space constraints or color figure charges

- Immediate publication on acceptance

- Inclusion in PubMed, CAS, Scopus and Google Scholar

- Research which is freely available for redistribution 